\title{
Mechanisms and Causes of Osteoporotic Hip Fractures in Elderly Patients
}

\author{
Yaşlı Hastalarda Osteoporotik Kalça Kırı̆̆ı Nedenleri ve Oluş Mekanizması \\ (1) Ayhan Ulusoy, (1) Serdar Demiröz* \\ Acıbadem Hospital, Clinic of Orthopaedics and Traumatology, Muğla, Turkey \\ *Medicalpark Hospital, Clinic of Orthopaedics and Traumatology, Kocaeli, Turkey
}

\section{Abstract}

Objective: To investigate the causes and occurrence mechanisms of osteoporotic hip fractures in elderly patients in Turkish society.

Materials and Methods: This study included 83 consecutive patients who were operated in our clinic due to hip fractures in $2013-2014$. The demographic characteristics of the patients, causes and types of fracture, occurrence mechanisms, and location of the fracture, as well as whether the patients lived alone and whether they used walking support were recorded. This information was evaluated retrospectively and analyzed by comparison according to the sex.

Results: Ninety-four percent of the patients fell on their right or left side hip joint, and 74\% of them fell due to balance disturbances, without any contributing environmental factors. Eighty percent of the patients were injured at home and $56 \%$ of them used walking assistance. Only $18 \%$ of the patients lived at home alone. According to the Body Mass index only 3\% of the patients were obese or overweight, while $49 \%$ were underweight.

Conclusion: Most patients with hip fracture over the age of 75 are low weight and living with caregivers. Most fractures occur via balance disturbances without any environmental factors and the majority of the patients' fall on one side, not to the front or back. Modifying the patient's clothes and floor materials to reduce the severity of trauma during fall can help reduce the incidence of hip fractures.

Keywords: Hip, fracture, cause, mechanism, elderly patients, osteoporosis

\section{Öz}

Amaç: Türk toplumunda yaşlı hastalarda osteoporotik kalça kırık nedenlerini ve oluş mekanizmasını araştırmak.

Gereç ve Yöntem: 2013-2014 yıllarında kalça kırığı nedeniyle kliniğimizde ameliyat edilen 83 ardışık hasta çalışmaya dahil edildi. Hastaların demografik özellikleri, kırık oluş nedenleri ve kırık tipleri, oluş mekanizması, kııığın olduğu yer, hastaların yalnız yaşayıp yaşamadığı ve yürümek için destek kullanıp kullanmadığı kaydedildi. Bu bilgiler retrospektif olarak değerlendirildi ve cinsiyete göre karşılaştırılarak analiz edildi.

Bulgular: Hastaların \%94'ü sağ veya sola doğru kalça eklemi üzerine ve \%74'ü herhangi bir çevresel faktöre bağlı olmaksızın dengelerini kaybederek düşmüştür. Düşmelerin \%80'i ev içinde olmaktadır ve hastaların \%56'sı yürümeye yardımcı destek kullanmaktadır. Hastaların sadece \%18'i evde yalnız yaşamaktadır. Vücut Kitle indeksi değerlerine göre hastaların sadece \%3'ü obez veya aşırı kilolu iken \%49'u düşük kiloludur.

Sonuç: Yetmiş beş yaş üstü kalça kırığı olan hastaların çoğu düşük kilolu ve bakım için yardım alan kişilerdir. Kırıkların çoğu herhangi bir çevresel faktöre bağlı olmaksızın denge kaybı nedeniyle oluşmaktadır ve hastaların çoğu öne ya da arkaya değil yan tarafa doğru düşmektedir. Hasta kıyafetlerinin ve zeminin düşme esnasında oluşan travma şiddetini azaltacak şekilde modifiye edilmesi kalça kırığı insidansını azaltmaya yardımcı olabilir.

Anahtar kelimeler: Kalça, kırık, neden, mekanizma, yaşı hastalar, osteoporoz

\section{Introduction}

With life expectancies increasing, the annual worldwide incidence of hip fractures is estimated to increase to more than 6 million by mid-century (1). Excessive alcohol consumption, physical inactivity, visual impairment, aging, female gender and especially osteoporosis are all risk factors for hip fractures $(2,3)$.
Globally, it is estimated that approximately one in three women and one in eight men over the age of 50 years old are at risk of osteoporotic fractures during their lifetimes (4). Although osteoporosis is the most important factor in hip fractures, it is not sufficient to produce them in and of itself. A fall from a standing height is the main mechanism of injury for fractures in elderly people, although several other factors can contribute, 
including falls from elevated heights and traffic accidents (5). An osteoporotic hip fracture is an important cause of morbidity and mortality in the older population. One-half of previously independent individuals become partly or totally dependent, with $5-20 \%$ dying within 1 year following such an injury (6). Moreover, the economic cost of these injuries is a significant issue. It is obvious that the incidence of osteoporotic hip fractures is an important healthcare problem which should be addressed.

The mechanism, incidence and pattern of fracture differ between populations due to climatological, sociological and demographic properties, and they also depend on environmental factors, the level of development, and the regulations of different populations (7). Therefore, different planning strategies and lifestyle recommendations, according to the population, are needed to prevent or decrease the incidence of osteoporotic hip fractures. There are several studies about the various mechanisms of hip fractures in the literature, but none that investigated a Turkish population. Thus, the aim of this study was to analyse the injury mechanisms and fracture patterns in individuals over 75 years old with proximal femur fractures in a Turkish population.

\section{Materials and Methods}

After obtaining institutional ethics committee review board approval, 83 consecutive patients (over 75 years old) who were operated on from 2013 to 2014 with the diagnosis of hip fractures were included in this study. Written informed consent, approved by our institutional review board, was obtained from all patient. Femoral neck, intertrochanteric and subtrochanteric fractures (up to $5 \mathrm{~cm}$ away from the trochanter minor) were accepted as hip fractures. Each of these patients filled out a questionnaire before undergoing surgery. The patients' demographics, causes and types of fractures, mechanisms, places and whether the patients lived alone and whether they used walking support were recorded, and their records were evaluated retrospectively and compared according to the sex. Those patients who had pathological fractures, a previous hip surgery, an inability to walk before the injury, and mental incompetence to answer the questions on the form were excluded from this research.

\section{Statistical Analysis}

All data were analysed using SPSS Statistics for Windows, version 20.0 (IBM Corp., Armonk, NY, USA). The MannWhitney $U$ test was used to compare the descriptive statistical measurements. Pearson's chi-square and Fisher's exact test were used to determine the differences between categorical variables. Statistical significance was determined as $p<0.05$.

\section{Results}

A total of 83 patients were included in this study; 25 (29\%) males and $58(71 \%)$ females with a mean age of $83 \pm 5$ years old. Twenty-four (28\%) were femoral neck, 53 (63\%) were intertrochanteric, and $6(7 \%)$ were subtrochanteric fractures. Only 15 (18\%) of the patients lived at home alone (Table 1). According to the body mass index values, $49 \%$ of the patients were underweight, with only $3 \%$ being overweight or obese. Most of the women patients used walking assistance and had IT fracture and it was statistically significant when compared according to the men (Table 2).

\section{Discussion}

The results of the present study revealed that over the age of 75 most patients with osteoporotic hip fractures are thin, with low body weight, and live with at least one other person. The fractures occurred most often at home via balance disturbances, without any associated environmental factors, and the majority of the patients fell on one side.

Body weight is an important factor in the occurrence of an osteoporotic hip fracture after falling down. Mussolino et

Table 1. Patient demographics and variables related to the hip fracture

\begin{tabular}{|l|l|}
\hline $\mathbf{n}$ & $\%$ \\
\hline
\end{tabular}

\begin{tabular}{l|l|l|} 
Sex & 25 & 30.1 \\
\hline Man & 58 & 69.9 \\
\hline Woman & \multicolumn{3}{|l}{$\begin{array}{l}\text { Mean } \pm \text { SD: 83 } \pm 5, \text { Median: } 83 \\
\text { minimum: } 75, \text { maximum: } 96\end{array}$} \\
\hline
\end{tabular}

\section{Reason for falling}

\begin{tabular}{|l|l|l|}
\hline Balance disturbance & 62 & 74.7 \\
\hline Environmental factors & 21 & 25.3 \\
\hline Direction of falling & & \\
\hline Lateral & 78 & 94.0 \\
\hline Posterior & 3 & 3.6 \\
\hline Anterior & 2 & 2.4 \\
\hline
\end{tabular}

Type of fracture

\begin{tabular}{|l|l|l|}
\hline IT & 53 & 63.9 \\
\hline CF & 24 & 28.9 \\
\hline ST & 6 & 7.2 \\
\hline Walking assistance & 36 & 43.4 \\
\hline No & 47 & 56.6 \\
\hline Yes & 47 &
\end{tabular}

Where the patient fell

\begin{tabular}{|l|l|l|}
\hline At home & 67 & 80.7 \\
\hline Outside & 16 & 19.3 \\
\hline Living alone & 15 & 18.1 \\
\hline Yes & 68 & 81.9 \\
\hline No &
\end{tabular}

n: Number, IT: Intertrochanteric, CF: Collum femoris, ST: Subtrochanteric, SD: Standard deviation 


\begin{tabular}{|c|c|c|c|c|c|c|}
\hline & \multicolumn{2}{|c|}{ Man } & \multicolumn{2}{|c|}{ Woman } & \multirow[b]{2}{*}{$\chi^{2 * *}$} & \multirow[b]{2}{*}{$\mathbf{p}^{* *}$} \\
\hline & $\mathbf{n}$ & $\%$ & $\mathbf{n}$ & $\%$ & & \\
\hline \multicolumn{7}{|c|}{ Reason for falling } \\
\hline $\begin{array}{l}\text { Balance } \\
\text { disturbance }\end{array}$ & 17 & 68.0 & 45 & 77.6 & \multirow{2}{*}{0.8} & \multirow{2}{*}{0.36} \\
\hline $\begin{array}{l}\text { Environmental } \\
\text { factors }\end{array}$ & 8 & 32.0 & 13 & 22.4 & & \\
\hline \multicolumn{7}{|c|}{ Type of fracture } \\
\hline CF & 11 & 47.8 & 13 & 24.1 & \multirow{2}{*}{4.2} & \multirow{2}{*}{0.04} \\
\hline IT & 12 & 52.2 & 41 & 75.9 & & \\
\hline $\mathrm{ST}^{*}$ & - & - & - & - & - & - \\
\hline \multicolumn{7}{|c|}{ Walking assistance } \\
\hline No & 15 & 60.0 & 21 & 36.2 & \multirow{2}{*}{4.0} & \multirow{2}{*}{0.045} \\
\hline Yes & 10 & 40.0 & 37 & 63.8 & & \\
\hline \multicolumn{7}{|c|}{ Where the patient fell } \\
\hline At home & 18 & 72.0 & 49 & 84.5 & \multirow{2}{*}{1.7} & \multirow{2}{*}{$0.23^{f}$} \\
\hline Outside & 7 & 28.0 & 9 & 15.5 & & \\
\hline \multicolumn{7}{|l|}{ Living alone } \\
\hline Yes & 20 & 80.0 & 48 & 82.8 & \multirow{2}{*}{0.1} & \multirow{2}{*}{$0.76^{f}$} \\
\hline No & 5 & 20.0 & 10 & 17.2 & & \\
\hline \multicolumn{7}{|c|}{$\begin{array}{l}\text { n: Number, IT: Intertrochanteric, CF: Collum femoris, ST: Subtrochanteric } \\
\text { *: Could not be analyzed because the number is insufficient } \\
\text { **: Pearson's chi-square test, 'FFisher's exact test }\end{array}$} \\
\hline
\end{tabular}

al. (8) found that a low body mass was associated with a higher risk of hip fracture. In addition, Farahmand et al. (9) and Langlois et al.(10) reported that a weight loss of $10 \%$ or more is associated with an increased risk of hip fracture. Ensrud et al. (11) explained this phenomenon by the fact that patients with smaller body sizes have lower bone mineral densities. Conversely, Maffulli et al. (12) reported that patients with trochanteric fractures tended to be overweight. They explained this via the formation of the trochanteric region from predominantly cancellous bone, which is metabolically more active than cortical bone. Moreover, overweight patients can have nutrient deficiencies affecting bone metabolism, such as calcium, vitamin K or vitamin C. In our study, $49 \%$ of the patients were underweight, while only $3 \%$ were overweight or obese. We believe that in addition to lacking the protective effect of adipose tissue, underweight patients suffer from malnutrition more often and have more comorbidities which may make them prone to falling.

Often, environmental factors can lead to falls causing hip fractures. Although King and Tinetti (13) reported that environmental factors may be important in cases of falls and fractures, Norton et al. (14) suggested the reverse. They reported that $85 \%$ of the falls resulting in hip fractures occurred at home, with $15 \%$ occurring outside, and only about $25 \%$ of the home falls were associated with environmental hazards.
Allander et al. (15) also suggested that environmental hazards were of minimal importance in mediating hip fractures. In our study, $82 \%$ of the patients were at home during their injuries, and $75 \%$ of the patients fell down due to balance disturbances, without any associated environmental factors. These results can be explained by the fact that those patients who could travel away from home were probably healthier than those who could not. Thus, it can be extrapolated that those patients who are older and in poor health tend to fall down without any environmental factors as a result of the inability to move about independently at home.

As people become older, their physical capacities decline. Moreover, the presence of cognitive impairment, such as depression, Alzheimer's disease and dementia, and disturbances in the mechanisms of balance predispose the elderly to falls, resulting in a higher incidence of hip fractures $(16,17)$. Impairments in perception, vestibular functions, proprioception and circulatory functions are seen most often in the elderly and can be related to balance disturbances $(18,19)$. The loss of vibration sense, reduced pain perception and absent Achilles and quadriceps reflexes also increase the hip fracture risk during falls (20). Therefore, an individual's general health status is one of the most important factors in determining whether a person will fracture their hip or not. In this study, we did not evaluate the patient-dependent physiological factors individually, but we did find that only $17 \%$ of the patients lived at home alone, with $83 \%$ of the patients living with at least one family member. Moreover, most of the patients used walking assistance. We concluded that those elderly patients who are not able to live alone and walk without support have a higher fracture risk.

Nankaku et al. (21) evaluated the hip fracture risk in relation to fall direction. Eight healthy volunteers performed deliberate falls in lateral, posterolateral and posterior directions on a platform. The fall descent motions and impact postures were then examined using a three-dimensional analyser. The ground force reaction, velocity at impact and activity of the quadriceps and gluteus medius muscles were measured. They reported that a fall in the posterolateral direction carried a higher risk of hip fracture. Hwang et al. (22) reported that elderly women who fell sideways were 12.8 -fold more likely to have a hip fracture than those who fell forward. In accordance with the literature, the majority of the patients (94\%) in our study fell to one side on their hips; therefore, we believe that, if it is possible, changing the direction of the fall by using walking assistant may be effective in decreasing the hip fracture rate.

When compared according to the sex there are significant differences between different populations. In eastern countries incidence rate of hip fracture similar between both sex or may be higher in men $(23,24)$. Yan $L$ et al. $(25)$ reported that the age-adjusted incidence rate of hip fracture was $67 / 100,000$ in women and $81 / 100,000$ in men in a chinese population. In contrast, the incidence rate of hip fracture was significantly higer in women (25-29). In this study, incidence rate of hip fracture was also higher in women $(p<0.05)$. In addition, 
when compared according to the sex, number of the patients using walking support was significantly higher in woman (Table 2).

Our study has several limitations such as relatively low number of patients and lack of dual-energy X-ray absorptiometry results of the patients which is an essential factor related to osteoporotic hip fracture.

\section{Conclusion}

Those patients with poor health statuses are more prone to osteoporotic hip fractures. Environmental changes, such as eliminating floor coverings and internal steps, and using shower and toilet railings, may seem to be useful but environmental factors have minimal effects on osteoporotic hip fractures, so these practices will not be beneficial. Changing the direction of the fall, educating the patient's accompanying relatives, and modifying the patient's clothes and floor materials to reduce the impact energy during a fall may help to reduce the incidence of osteoporotic hip fractures.

\section{Ethics}

Ethics Committee Approval: The study were approved by the Local Ethics Committee of Medicalpark Hospital (Protocol number: 2019-2-3).

Informed Consent: Consent form was filled out by all participants.

Peer-review: Internally peer-reviewed.

\section{Authorship Contributions}

Surgical and Medical Practices: A.U., Concept: A.U., Design: A.U., Data Collection or Processing: A.U., Analysis or Interpretation: S.D., Literature Search: S.D., Writing: S.D.

Conflict of Interest: No conflict of interest was declared by the authors.

Financial Disclosure: The authors declared that this study received no financial support.

\section{References}

1. Cooper C, Campion G, Melton LJ 3rd. Hip fractures in the elderly: a world-wide projection. Osteoporos Int 1992;2:285-9.

2. Wiklund R, Toots $A$, Conradsson M, Olofsson B, Holmberg $H$, Rosendhal $E$, et al. Risk factors for hip fracture in very old people: a population based study. Osteoporos Int 2016;27:923-31.

3. Cummings SR, Nevitt MC, Browner WS, Stone K, Fox KM, Ensrud KE, et al. Risk factors for hip fractures in white women. Study of Osteoporotic Fractures Research Group. N Engl J Med 1995;332:814-5.

4. Woolf $A D$, Pfleger B. Burden of major musculoskeletal conditions. Bull World Health Organ 2003;81:646-56.

5. Parkkari J, Kannus P, Palvanen M, Natri A, Vainio J, Aho H, et al. Majority of hip fractures occur as a result of a fall and impact on the greater trochanter of the femur: a prospective controlled hip fracture study with 206 consecutive patients. Calcif Tissue Int 1999;65:183-7.

6. Kannus $P$, Niemi S, Parkkari J, Palvanen $M$, Vuori I, Järvinen $M$. Hip fractures in Finland between 1970 and 1997 and predictions for the future. Lancet 1999;353:802-5.
7. Melton LJ 3rd, Crowson FS, O'Fallon WM. Fracture incidence in Olmsted County, Minnesota: comparison of urban with rural rates and changes in urban rates over time. Osteoporos Int 1999;9:2937.

8. Mussolino ME, Looker AC, Madans JH, Langlois JA, Orwoll ES. Risk factors for hip fracture in white men: The NHANES I Epidemiologic Follow-up Study. J Bone Min Res 1998;13:918-24.

9. Farahmand BY, Michaëlsson K, Baron JA, Persson PG, Ljunghall S. Body size and fracture risk. Swedish Hip Fracture Study Group. Epidemiology 2000;11:214-9.

10. Langlois JA, Visser M, Davidovic LS, Maggi S, Li G, Harris TB . Hip fracture risk in older White men is associated with change in body weight from age 50 years to old age. Arch Int Med 1998;158:990-6.

11. Ensrud KE, Lipschutz RC, Cauley JA, Seeley D, Nevitt MC, Scott J, et al. Body size and hip fracture risk in older women: a prospective study. Am J Med 1997;103:274-80.

12. Maffulli N, Dougall TW, Brown MT, Golden MH. Nutritional differences in patients with proximal femoral fractures. Age Ageing 1999;28:458-62.

13. King MB, Tinetti ME. A multifactorial approach to reducing injurious falls. Clin Geriatr Med 1996;12:745-59.

14. Norton R, Campbell AJ, Lee-Joe $T$, Robinson E, Butler $M$. Circumstances of falls resulting in hip fractures among older people. J Am Geriatr Soc 1997;45:1108-12.

15. Allander E, Gullberg B, Johnell O, Kanis JA, Ranstam J, Elffors L. Circumstances around the fall in a multinational hip fracture risk study: a diverse pattern for prevention. Accid Anal Prev 1998;30:607-16.

16. Boonen S, Dequeker J, Pelemans W. Risk factors for falls as a cause of hip fracture in the elderly. Acta Clin Belg 1993;48:190-4.

17. Falch JA, Kaastad TS, Bøhler G, Espeland J, Sundsvold OJ. Secular increase and geographical differences in hip fracture incidence in Norway. Bone 1993;14:643-5.

18. Baker SP, Harvey AH. Fall injuries in the elderly. Clin Geriatr Med 1985;1:501-12.

19. Grisso JA, Kelsey JL, Strom BL, Chiu GY, Maislin G, O'Brien LA, et al. Risk factors for falls as a cause of hip fracture in women. The Northeast Hip Fracture Study Group. N Engl J Med 1991;324:1326-31.

20. Luukinen H, Koski K, Laippala P, Kivelä SL. Factors predicting fractures during falling impacts among home-dwelling older adults. J Am Geriatr Soc 1997;45:1302-9.

21. Nankaku M, Kanzaki H, Tsuboyama T, Nakamura T. Evaluation of hip fracture risk in relation to fall direction. Osteoporos Int 2005;16:1315-20.

22. Hwang HF, Lee HD, Huang HH, Chen CY, Lin MR. Fall mechanisms, bone strength, and hip fractures in elderly men and women in Taiwan. Osteoporos Int 2011;22:2385-93.

23. Rowe SM, Yoon TR, Ryang DH. An epidemiological study of hip fracture in Honam, Korea. Int Orthop 1993;17:139-43.

24. Xu L, Lu A, Zhao X, Chen X, Cummings SR . Very low rates of hip fracture in Beijing, People's Republic of China: The Beijing osteoporosis project. Am J Epidemiol 1996;144:901-7.

25. Yan L, Zhou B, Prentice A, Wang X, Golden MH. Epidemiological Study of Hip Fracture in Shenyang, People's Republic of China. Bone 1999;24:151-5.

26. Jéquier $V$, Burnand $B$, Vader JP, Paccaud F. Hip fracture incidence in the Canton of Vaud, Switzerland, 1986-1991. Osteoporos Int 1995:5:191-5.

27. Lau EM, Cooper C, Wickham C, Donnan S, Barker DJ. Hip fracture in Hong Kong and Britain. Int J Epidemiol 1990;19:1119-21.

28. Mazzuoli GF, Gennari C, Passeri M, Celi FS, Acca M, Camporeale A, et al. Incidence of hip fracture: an Italian survey. Osteoporos Int 1993;3(1 Suppl):8-9.

29. Wong PC. Fracture epidemiology in a mixed Southeastern Asian community (Singapore). Clin Orthop Relat Res 1966;45:55-61. 